\section{DIGITAL COMMONS \\ @ UNIVERSITY OF SOUTH FLORIDA}

\section{ABO: Interactive Journal for Women in the Arts, 1640-1830}

Volume 7

Issue 2 Volume 7.2 (Fall 2017)

Article 5

2017

\title{
Review of Heteronormativity in Eighteenth-Century Literature and Culture
}

Kevin Bourque

Elon University, kbourque2@elon.edu

Follow this and additional works at: https://digitalcommons.usf.edu/abo

Part of the Dramatic Literature, Criticism and Theory Commons, Educational Methods Commons, Feminist, Gender, and Sexuality Studies Commons, and the Literature in English, British Isles Commons

\section{Recommended Citation}

Bourque, Kevin (2017) "Review of Heteronormativity in Eighteenth-Century Literature and Culture," ABO: Interactive Journal for Women in the Arts, 1640-1830: Vol.7: Iss.2, Article 5.

http://doi.org/10.5038/2157-7129.7.2.1169

Available at: https://digitalcommons.usf.edu/abo/vol7/iss2/5

This Reviews is brought to you for free and open access by Digital Commons @ University of South Florida. It has been accepted for inclusion in ABO: Interactive Journal for Women in the Arts, 1640-1830 by an authorized administrator of Digital Commons @ University of South Florida. For more information, please contact digitalcommons@usf.edu. 


\section{Review of Heteronormativity in Eighteenth-Century Literature and Culture}

\section{Keywords}

eighteenth century, heteronormativity, queer theory, LGBTQ studies

Creative Commons License

(c) (i) (9)

This work is licensed under a Creative Commons Attribution-Noncommercial 4.0 License 
Ana de Freitas Boe and Abby Coykendall, eds. Heteronormativity in Eighteenth-Century Literature and Culture. Routledge, 2016. xiii + 219pp. ISBN: 978-1472430175.

Reviewed by Kevin Bourque

Elon University

Two epigraphs preface Heteronormativity in Eighteenth-Century Literature and Culture: Supreme Court Justice Anthony Kennedy's ruling in the landmark gay marriage decision of 2013, where he blithely characterizes "marriage between a man and a woman" as a constant throughout history, and Edmund Burke's 1757 assertion that every reader has experienced the "strong desire for a woman of no remarkable beauty." The Janus-faced gesture entirely suits the collection. Even as it engages with the insidiousness of heteronormativity - the way, as in the presuppositions of Burke and Kennedy, heterosexuality remains monolithic because it goes unquestioned-Boe and Coykendall's collection maintains a continual, generative tension between the 1700s and the present day. These essays look backward, interrogating how presentday heteronormativity obviates accurate critical encounters with the 1700s; at the same time, they gesture forward, tracing how eighteenth-century heteronormativities shaped more modern institutions of sex, gender and sexuality. This transhistorical approach positions the volume as a considerable contribution both to eighteenth-century studies and to queer historiography writ large.

The editors bookend the collection with object lessons on how resisting heteronormativity might produce more rigorous and authentic depictions of the period: Susan Lanser's engaging, elegantly written "Of Closed Doors and Open Hatches: Heteronormative Plots in Eighteenth-Century (Women's) Studies" and "Teaching Eighteenth-Century Literature in a Transgendered Classroom," a pedagogy piece coauthored by Kirsten Saxton, Ajuan Maria Mance and Rebekah Edwards. Lanser's contribution reviews eighteenth-century historiography, particularly the work of Amanda Vickery, to expose the ease with which scholars project modern-day heteronorms onto the past. In result, eighteenth-century studies is frequently "more heteronormative than the eighteenth century itself" (28). Subsequent chapters answer Lanser's clarion call to recuperate the queer eighteenth century. In precise, textured prose, Abby Coykendall surveys the critical reception of Thomas Gray and Horace Walpole, revealing how two hundred years of criticism has conspired to contain the homoeroticism of the former and the "unabashed effeminacy" of the latter (123). George Haggerty underscores how gothic novels, too often construed by critics as "messy" or "failures," in fact resist and subvert cultural (hetero)norms. And in "John Gabriel Stedman, Heteronormativity, and White Men's Gender Trouble," Ana de Freitas Boe reads Stedman's Narrative of a Five Years Expedition against the Revolted Negroes of Surinam (1790) as a corrective to "postcolonial and feminist criticism of the eighteenth century," which typically overlooks or "ignores the homoerotics of the colonial encounter" (152). In tandem, such essays correct anachronistic depictions "of heterosexuality as a timeless, transcultural phenomenon" (5) and work to "restore an eighteenth century that is queerer than scholarship has been inclined to allow" (39).

Other authors approach by way of the "deep" eighteenth century—as Joseph Roach characterizes it, the eighteenth century that yet lingers with us - in situating modern heteronormativities as aftereffects of the Enlightenment. Theresa Braunschneider traces rape culture to its eighteenth- 
century contexts in her analysis of the "Monster scare," a media panic centering on a series of attacks in 1790, whose documents "paint a picture of a social world - a remarkably sexualized one, marked by frequent physical contact and flirtatiously flattering speech - in which men understand themselves to be practicing ideals of masculine politeness while women feel threatened by that very behavior" (105). "Conjugal Capitalism: The Domestication of Public Space," Sally O'Driscoll's contribution, studies how the policing of public space displaced sodomites and prostitutes to provide space for shopping - and how this correspondingly constructed the identities of the sex deviant and the domestic woman. O'Driscoll's concern with space resurfaces elsewhere, in chapters linking heteronormativity to new conceptions of privacy: Chris Roulston's examination of the wedding night in France, which through the course of the century shifts marriage "from the public sphere into an intensely private realm" (65) and Declan Kavanagh's evocative reading of John Wilkes's An Essay on Woman, which demonstrates how the enlightenment granted male heterosexuality the "new sovereignty" of privacy, at the expense of "non-heteroerotic forms of sexuality" $(81,78)$, such as sodomy. These chapters augment and complicate the work of those, like Foucault, Laqueur and Katz, who present the Enlightenment as the origin of binary gender, companionate marriage, even heterosexuality itself. In turn, because the authors are conversant in contemporary trends in queer theory (among others, the chapters engage with the work of Butler, Berlant, Warner, Dinshaw, Sedgwick and Halberstam), Heteronormativity in Eighteenth-Century Literature and Culture foregrounds the eighteenth century's relevance to queer studies, regardless of period.

As the volume's epigraphs would suggest, the contributions - in different ways - look backwards and forwards at once: alongside her corrective to critics, for example, Boe suggests that "race and miscegenation shaped emergent heteronormative conceptions of sexuality" which yet remain with us (165), and Kavanagh stresses a new reading of Wilkes in historical context, less as "a libertine politician melding sexuality and politics" and more a man who "sought to divorce and protect heterosexuality from the political" (79). While the contributions speak eloquently to the eighteenth century and to our own time, however, they don't consistently or universally speak to each other. "Heteronormativity" is a thorny concept, and the authors conceptualize it differently through the volume, and toward different ends; heteronormativity in the Introduction "comprehends the entire array of polarized taxonomies that organize compulsory heterosexuality and generate its aura of obviousness" (7), while elsewhere authors treat it in a more limited fashion, as a mechanism merely of binary gender or as roughly commensurate with "social norms." But heteronormativity is, by its nature, difficult to pin down; it thrives on seeming too obvious to name, while it is in truth so vexed that no one model can completely interrogate it. (For this reason, a collection might be the best possible way to approach the subject.) The volume's overall focus on heteronormativity, as opposed to queer identity, is also an asset in that it neatly sidesteps problems faced by similar collections: how can we write about LGBTQ issues in a period before LGBTQ identities could rightly be said to exist? or read the period in ways that don't presuppose the arrival of such identities? Chris Mounsey and Caroline Gonda's Queer People: Negotiations and Expressions of Homosexuality, 1700-1800 (2007), for example, bifurcates its contents into separate sections devoted to "Social Constructionism" and "Essentialist Historicism." In focusing on heteronormativity, the collection privileges an unbroken connection between past and present, arguably its greatest strength. 
In sum, Heteronormativity in Eighteenth-Century Literature and Culture features innovative scholarship with far-reaching implications. Its thoughtful attention to the eighteenth century, the present day and the longue durée between make the volume useful to critics of the eighteenth century, those interested in the history of sex, gender and sexuality, and queer studies scholars more broadly. Critics of the "long eighteenth" should take example from the mindfulness with which these authors engage with the past, and inspiration from the radical potential such careful attention might engender. "[T]he eighteenth-century culture that forged modern heteronormativity," writes Susan Lanser in the first chapter, "also planted seeds of its unmaking that are still flourishing today" (36). The present-day potential to unmake heteronormativity- to envision and assert queerness in the present-relies on an unblinkered, unbiased estimation of the past. Boe and Coykendall's collection performs that important work. 